\title{
Is good teaching culturally responsive?
}

\author{
Madalina Tanase \\ University of North Florida, United States
}

\begin{abstract}
Demographic data show an increasingly diverse student population in all urban settings. This contrasts with the teacher force, which is predominately middle class, female, monolingual, and of European ancestry. This discrepancy adds complexity to an already complex profession. To bridge this cultural gap, researchers advocate for a change in the teaching paradigm, in which teachers understand the relationship between students' culture and learning. This paradigm is called Culturally Responsive Teaching. The participants of this study were twenty-two secondary mathematics and science teachers. The researcher analyzed whether some of the strategies used in mathematics and science urban classrooms were studentcentered as well as culturally responsive. Results show that teachers used a variety of student-centered strategies, such as discovery learning, centers and group work, and games. Similarly, the teachers incorporated their students' culture into their mathematics and science classrooms, by including their students' interests in the lessons, exposing students to similar role models, and using real-life examples that students found relatable.
\end{abstract}

Keywords: Urban settings; Culturally responsive teaching; Middle school; High school

Article History: Submitted 27 July 2020; Revised 12 September 2020; Published online 15 September 2020

\section{Introduction}

The student population in urban settings is increasingly diverse. The Report on Racial Diversity in the Educator Workforce revealed that in the 2011-2012 school year, $51 \%$ of all public-school students were Caucasian, $16 \%$ were African American, and $24 \%$ were Hispanic (US Department of Education, 2016). In comparison, $82 \%$ of public-school teachers were Caucasian, $7 \%$ were African American, and 8 \% were Hispanic. To Gay (2013), this discrepancy adds a "layer of complexity to implementing culturally responsive teaching and makes linking it explicitly to regular classroom functions even more important." (p. 64) To bridge the cultural mismatch, Ullucci and Howard (2015) urged teacher educators to offer new perspectives on educating students from impoverished backgrounds. Similarly, Gay (2010) advocated for educating teachers to incorporate their students' culture into teaching.

This approach to teaching, in which teachers understand the relationship between students' culture and learning is known as culturally responsive teaching (hereafter CRT) or culturally responsive pedagogy (hereafter CRP). Banks (2011) named this approach to teaching equity pedagogy. The need for CRT is further stressed by the National Education Association (n.d.):

Address of Corresponding Author

Madalina Tanase, PhD, University of North Florida, College of Education and Human Services, Jacksonville, FL, 32256.

$\triangle$ madalina.tanase@unf.edu

0000-0002-8385-6765

How to cite: Tanase, M. (2020). Is good teaching culturally responsive?. Journal of Pedagogical Research, 4(3), 187-202. 
Culturally competent teaching is increasingly necessary if educators are to connect with their students. And to connect, educators need to acquire new teaching strategies that match students' way of understanding and interacting with the world. These approaches will help increase student performance as measured by grades and tests, enhance student access to a more rigorous curriculum, and advance student attainment to high school completion and beyond.

Similarly, Howard (2010) and Banks (2011) stressed the role that CRT plays in closing the achievement gap between cultural groups. To Howard (2010), CRT is a response to ongoing achievement gaps between African Americans, Caucasians, certain Asian Americans, and Latinos. Banks (2011) believed that the academic achievement of African American students can be increased when teachers have cultural competency in the cultures of their students and design activities which build upon the cultural and linguistic strengths of students. In addition, Rychly and Graves (2012) stipulated that if diverse students were underachieving because of cultural differences in the ways they learned best and the ways they were taught, American students would continue to underachieve unless teachers change the ways they teach. Banks (2011) talked about a transformation of education in the 21st century, because of the deepening racial, ethnic, cultural, and language diversity around the world:

Students should develop a balance of cultural, national, and global identifications. A nation-state that does alienate and does not structurally include all cultural groups into the national culture runs the risk of creating alienation and causing groups to focus on specific concerns and issues rather than on the overarching goals and policies of the nation-state. (p. 157)

It thus becomes necessary for teachers to develop a repertoire of strategies that tap into their students' cultural and ethnic potential, in order to maximize learning and to close the achievement gap between cultural groups. This occurs if and when teachers are willing to learn about their students' culture, and to use these funds of knowledge (Velez-Ibanez \& Greenberg, 1992) when they design and implement their lessons in their diverse classrooms.

\subsection{Literature Review}

\subsubsection{Culturally responsive teaching: Definitions, curriculum, and pedagogy}

What is CRT? According to Gay (2010), CRT is the paradigm needed to embed culture within the teaching:

A very different pedagogical paradigm is needed to improve the performance of underachieving students from various ethnic groups-one that teaches to and through their personal and cultural strengths, their intellectual capabilities, and their prior accomplishments. Culturally responsive teaching is this kind of paradigm. (pp. 26-27)

There are currently many definitions centered around CRT. An earlier definition comes from Ladson-Billings (2001), who reflected: "Culturally relevant pedagogy urges collective action grounded in cultural understandings, experiences and ways of knowing of the world" (p. 202). Teel and Obidah (2008) described CRT as creating learning communities where cultural heritages are valued, by using cultural knowledge of the diverse communities to guide curriculum development and to challenge the status quo. For Howard (2010), CRP embodied:

a professional, political, cultural, ethical, and ideological disposition that supersedes mundane teaching acts; it is centered in fundamental beliefs about teaching, learning, students, and their families, and their communities, and an unyielding commitment to see student success become less rhetoric and more of a reality (p. 67). 
Moreover, Rychly and Graves (2012) reflected that CRP responded to the cultures present in the classroom by connecting new information to students' background knowledge and presenting in ways that respond to students' natural ways of learning. Furthermore, Gay (2002) reflected:

In culturally responsive teaching the "knowledge" of interest is information about ethnically diverse groups; the "strategic thinking" is how this cultural knowledge is used to redesign teaching and learning; and "the bounds" are the reciprocity involved in students working with each other and with teachers as partners to improve their achievement (pp. 109-110).

More recently, Gay (2018) defined CRT as "using the cultural knowledge, prior experiences, frames of reference, and performance styles of ethnically diverse students to make learning encounters more relevant to and effective for them." (p. 36) In culturally rich environments students are held accountable for one another's success; all students are winners and they all assume responsibility for helping one another to achieve to the best of their ability.

Similarly, researchers have reflected on the goals and value of CRT. For Ladson-Billings (2001), the goal of CRT is to prepare students to critically examine the society in which they live and to work for social change. Au (2009) argued that teachers should build on the background knowledge and experiences gained in the home and community in order to "close the achievement gap between students of diverse backgrounds and their mainstream peers" (p. 179). In turn, Howard (2010) reflected that CRT sought to develop consciousness and commitment to social justice wherein students understand the social, historical, and political issues and identify and address inequities. In addition, Rajgopal (2011) believed that CRT was empowering, as it enabled students to be better human beings and more successful learners, while Gay (2018) described CRT as affirming, as "it builds bridges of meaningfulness between home and school experiences" as well as "it uses a wide variety of instructional strategies that are connected to different learning styles" (p. 37).

Culturally responsive curriculum. Gay (2018) believed that curriculum content can empower students if the knowledge students acquire is accessible to them and meaningful for their lives outside of school: "Content about the histories, heritages, contributions, perspectives and experiences of different ethnic groups and individuals, taught in diverse ways, is essential to culturally responsive teaching" (p. 127). Textbooks continue to be prominent teaching tools (Crum, 2015; Rosenwald, 2015), as most students consider textbooks incontestable sources of information (Gullicks et al., 2005). When conducting a curriculum analysis, Sleeter and Grant (1991) found that textbooks were dominated by European-Americans, as they conformed to their status, culture, and contributions. Banks (2011) found that the West paradigm in American history and culture continued to permeate the school curriculum at all levels. Banks thus argued that "the West paradigm must be seriously examined and deconstructed in order for students to acquire a deep, complex, and compassionate understanding of U.S. history and culture" (Banks, p. 86). Similarly, Gay (2018) argued that textbooks were flawed in their treatment of cultural diversity, and they continued to be far from ideal. The upside, according to Giarrizzo (2013), was that African Americans received more coverage; the downside, however, was that the information tended to be stereotypical, negative, or superficial.

Given the influence of the curriculum on learning, how can teachers help their students understand the social, historical, and political issues and address inequities that exclude marginalized groups? Gay (2010) believed that teachers should push their students to critique teaching resources and strategies, and conduct their own analyses of textbooks, mass media, Internet, literary sources, and personal narratives. Together, they can examine multiple ethnic descriptions of events and replace existing presentations of issues with their own acquired cultural knowledge and insights. Banks (2011) further advised that students must be taught that since the concept of the West is a Eurocentric idea, different groups conceptualized and viewed the West differently. When teachers help students view Eurocentric concepts from different perspectives 
(i.e. the West, the discovery of America), they can increase their students' ability to determine the implicit perspectives embedded in curriculum materials and to become more reflective citizens. As Gay (2018) concluded: "Much more cultural content is needed in all school curricula about all ethnic groups of color. The need is especially apparent in math and science and for ethnic groups other than African-American" (p. 192). This cultural content, as Gay (2018) argued, cannot be drawn from one source alone. Teachers need to use various resources (textbooks, music, personal experiences, mass media, etc.) to provide students with more accurate cultural information about groups of color to fill knowledge voids or clear misconceptions.

Culturally responsive pedagogy. According to Kroeger and Bauer (2006), American traditional classrooms have developed from Western European traditions:

The classroom culture you are most likely to see and experience is based on white, AngloSaxon, protestant roots with core values of individualism and freedom. There is an assumption that anyone from outside the majority culture will somehow conform to or assimilate these values and ways of perceiving the world (p. 29).

Similarly, Gollnick and Chin (2002) and Spindler and Spindler (1990) identified individualism and freedom as paramount values of the dominant group. But are these values imprinted in the DNA of the diverse students who make up the majority of the US classrooms? The above researchers found mainstream values to differ radically from the values of ethnically diverse groups: while individualism, competition, personal achievement, and success were fundamental Western values, diverse groups valued cooperation, the group's well-being, and interdependence.

When discussing the pedagogy of place, Raymer (2001) believed that learning occurred when students connected subject matter to their own lives and surroundings and critically reflected upon the connection and the materials being studied. Learning happened when students saw themselves as products and creators of interconnections among people and places. Banks and Banks (2011) talked about equity pedagogy, which they defined as strategies that "help students from diverse racial, ethnic, and cultural groups to attain the knowledge, skills, and attitudes needed to function effectively within and to help create and perpetuate a just, humane, and democratic society." (pp. 92-93) According to the researchers, equity pedagogy exists when teachers adapt their teaching to meet the needs of diverse students.

Is good teaching CRT? Yes, in the sense that there are some universal strategies (i.e. cooperative learning strategies) that enhance learning in general (Au, 2009; Slavin, 2014); in particular they enhance the learning of minority students (Banks, 2011; Gay, 2018; Powell \& Caseau 2004). And no, because culture permeates all aspects of our lives, including how we teach and learn. According to Gay (2000):

Many educators still believe that good teaching transcends place, people, time, and context. They contend it has nothing to do with the class, race, gender, ethnicity, or culture of students and teachers...Individuals who subscribe to this belief fail to realize that their standards of "goodness" in teaching and learning are culturally determined and are not the same for all ethnic groups. (p. 23)

In order to achieve educational equity and excellence (Gay, 2010), teachers should employ a variety of resources and teaching techniques (i.e. cooperative learning strategies, discussions, etc). Cooperative learning has been deemed an essential tool for CRT because cooperation and collaboration are prominent in educating marginalized Latinxs, native Africans, and Asian Americans. According to Gay (2018), this is due to the fact that connectedness and collaborative problem-solving are high priorities in the cultures of most groups of color. Moreover, cooperation plays a central role in these groups' learning styles. Many researchers addressed the benefits of cooperative learning in relation with CRT. For Gay (2018), cooperative teaching and learning "can create psycho-emotional "safe spaces" and culturally responsive "grace spaces" ... and can 
increase congruence among students' preferred ways of personal being, intellectual engagement, and academic task performance." (p. 220)

Similarly, Gillies (2014), Morgan (2012), and Slavin (2014) believed that cooperative learning forged more interethnic social interactions and friendships and it increased academic achievement, resulting in higher levels of confidence and efficacy for students of color, better engagement and learning tasks, and intrinsic motivation. Kagan (1994) believed that cooperative learning lead to academic gains, improved race relations among students, and improved social and affective development among all students; the researcher thus urged teachers interested in CRT to "give serious attention to cooperative learning methods." (p. 196)

However, Banks (2011) urged teachers to pay attention to how they used cooperative learning, as implementing such strategies would not necessarily result in equity pedagogy. For this to happen, students need to be actively involved in the process of knowledge construction and production. The goal of equity pedagogy is to challenge the idea of instruction as transmission of facts and the image of the teacher as a citadel of knowledge and students as passive recipients. Cooperative learning should enable students to construct knowledge as well as envision new possibilities for the use of that knowledge for societal change.

Another CRT strategy is the group work and discussion. Powell and Caseau (2004) considered small group discussions effective instructional tools, as they moved students from passive to active modes of learning. Moreover, small group work increased problem solving, creative and critical thinking, social skills development, and the students' cultural sensitivity. These researchers deemed group work as "preferred modes of learning for females, Native Americans, African Americans, and Latins." (p. 193) Likewise, Gay (2000) believed that the African American, Asian, Native American, and Latino American communal cultural systems relied on peer teaching and group work in order to improve student learning.

Not all group work automatically becomes CRT. For groups to function in a manner consistent with a diverse worldview, Au (2009) believed that the teachers should guide students to develop ground rules that promote student collaboration. Similarly, Gay (2018) believed that groups may not work well when teachers assign students to groups to work on specific tasks; rather, teacher and students should develop together the criteria for selecting group members and assigning the tasks. And while Banks (2011) believed that students learn from peers, he urged teachers to make provisions "for dealing with the status differences among students based on race, gender, and social class" (p. 97). Incorporating group work without paying attention to the above factors could further marginalize students from low status groups, rather than enabling them to learn from their peers.

As a conclusion to the above, culturally relevant teachers need to use strategies that facilitate learning for all students. Banks (2011) argued students should be pushed to generate knowledge and solutions and to create new understandings. Moreover, Gay (2010) reflected that matching teaching strategies to the learning styles of different ethnic groups may be connected to providing students with a variety of options for demonstrating mastery of academic content (i.e. essays, letters, dialogues, photo collages). According to Gay (2010), teachers should develop repertoires of culturally diverse examples which they should use fluidly in classroom instruction. And since music and movement benefit the performance of African American students, researchers (Allen \& Butler, 1996; Gay, 2018) advised teachers to incorporate music and movement into learning. Lastly, $\mathrm{Au}(2009)$ believed that CRT should not duplicate home and community settings in the classroom, rather, it should be a hybrid, or a "blending of elements from students' home cultures with elements typical of the classroom and academic learning." (p. 180).

\section{Method}

\subsection{Participants and Context}

Thirteen mathematics and nine science novice teachers participated in this study. All participants graduated from an urban graduate Teacher Residency program from a mid-sized university in the 
southeastern United States. The researcher had previously taught the participants as they were undergoing the program, and upon completion, the researcher asked all former students to participate in the study; only twenty-two agreed to participate.

Table 1.

Participants

\begin{tabular}{|c|c|c|c|c|}
\hline Gender & Male: 9 & Females: 13 & & \\
\hline Ethnicity & Caucasians: 13 & African-Americans: 7 & Latinx: 1 & Asian: 1 \\
\hline Content area & Mathematics: 13 & Science: 9 & & \\
\hline Cohorts & $\begin{array}{l}\text { Cohort 1: started } \\
\text { teaching Fall } 2016\end{array}$ & $\begin{array}{l}\text { Cohort 2: started } \\
\text { teaching Fall } 2017\end{array}$ & $\begin{array}{l}\text { Cohort } \\
2018\end{array}$ & aching Fall \\
\hline
\end{tabular}

There were thirteen female and nine male teachers of an age average of thirty. Thirteen teachers were Caucasians, seven African-American, one Asian, and one Latina. The teachers belonged to three different cohorts: cohort 1 (who started teaching in the Fall 2016), cohort 2 (who started teaching in the Fall 2017), and cohort 3 (who started teaching in the Fall 2018).

The directors of the residency program, in collaboration with the school district, placed the teachers in eight urban middle and high schools in the city where they graduated. According to The Center for Technology in Education (2018), urban schools generally have larger enrollments than suburban or rural schools, mostly serving low income students. Behavior problems in the areas of absenteeism, classroom discipline, and weapons possession are more common in urban schools. Moreover, $40 \%$ of urban students attend high poverty schools, where more than $40 \%$ receive free/reduced lunches. On average, students in urban schools have lower achievement scores than students in suburban schools. The directors of the residency programs chose the schools because they met the criteria of low-income, high-poverty schools, and they were situated in the poorest area of the city.

Table 2.

Context of the Schools

\begin{tabular}{llll}
\hline Mean Annual Income & National: \$55, 322 & \multicolumn{2}{l}{ School Neighborhood: \$25, 971 } \\
\hline School Population & African-Americans: 90\% & Caucasians: 2-4\% & Latinx: 1-3\% \\
\hline $\begin{array}{l}\text { School Performance } \\
\text { (2015-2016) }\end{array}$ & Graduation: 75\% & Drop out: 3\% & \\
\hline
\end{tabular}

The mean annual income of the neighborhoods in which the teachers taught was $\$ 25,971$, while the mean national income was $\$ 55,322$. All the schools were historically black, with over $90 \%$ African American students, 1-3\% Latinx, and 2-4\% Caucasian students. According to the Florida Department of Education website, the graduation rate for these schools in the year 2015-2016 was $75 \%$, while the dropout rate was 3\%. Moreover, $70 \%$ of the students were low income, and all the schools offered free/reduced lunches. The school district rated these schools with the grades of $B$ (average) and C (below average) (Florida Department of Education n. d.).

\subsection{Research Design and Instrument}

The data in this manuscript were part of a longitudinal study, which started in 2016 and ended in 2018. The researcher interviewed the cohort 1 participants for the first time in 2016. In 2017, the researcher interviewed the participants in cohorts 1 and 2, and in 2018, the researcher interviewed the participants in all three cohorts. Overall, the researcher collected more data from cohort 1, who were interviewed on three occasions (in 2016, 2017, and 2018). Participants in cohort 2 were interviewed on two occasions (in 2017 and 2018), while participants in cohort 3 were only interviewed in one occasion, in 2018. As the approval of the study ended in 2018, the researcher could not obtain more data from participants in cohorts 2 and 3 . Because there were more data from cohort 1 , in the current study the researcher only used the data collected in the first year of 
teaching for all participants for uniformity reasons. Other studies will analyze all the longitudinal data obtained from the three cohorts, analyzing any changes in the participants' use of strategies.

The instrument used in this study was a teacher interview developed by the researcher. The participants answered six open-ended questions that were directed at instructional strategies. For example, the participants were asked to describe the strategies and activities they used to teach their students science and mathematics, as well as to reflect whether and how they integrated their students' culture into their teaching. All the questions are included in Appendix 1. This instrument, in addition to a demographic questionnaire, was administered at the beginning of the participants' first year of teaching.

\subsection{Data Analysis}

The researcher conducted a content analysis of all interviews to identify the participants' understanding of CRT, and the strategies they used to teach mathematics and science. The researcher used content analysis to classify words that had similar meanings into categories (Cavanagh, 1997) with the aim "to attain a condensed and broad description of the phenomenon" (Elo \& Kyngäs, 2008, p. 108). While interpreting the data, the researcher grouped the statements into categories, and further named these categories using content-characteristic words. The researcher used the N-VIVO software (9th edition), a computer-assisted qualitative data analysis program. To discover connections among the nodes, the researcher analyzed the refined data sets from the teacher interviews. Two main themes emerged from the data set: a) the teachers used student-centered strategies to teach mathematics and science, and b) the teachers incorporated students' culture into their mathematics and science classrooms. When analyzing the data, the researcher focused on the research questions that guided this qualitative study: 1) What strategies do culturally responsive teachers use in their mathematics and science classroom? 2) How do these teachers incorporate their students' cultures into teaching?

The above data generated other categories, which could not all be captured in this paper, given the length limitations imposed on research papers in general. The researcher used the data in the two themes described above to make the case for this paper. Other categories include, for example: making connections with real-life in mathematics and science classrooms, and enabling students to make choices in their learning. Each of these two categories is further divided into sub-categories. These data make the subject of another paper.

\section{Results}

I divided the findings into two main categories: 1) the teachers used student-centered strategies to teach mathematics and science, and 2) the teachers incorporated students' culture into their mathematics and science classrooms. Each category was further divided in sub-categories.

Table 3.

Themes and Sub-Themes

\begin{tabular}{llll}
\hline Themes & Sub-themes & Sub-themes & Sub-themes \\
\hline $\begin{array}{l}\text { Teachers used student-centered } \\
\text { strategies }\end{array}$ & Discovery learning & $\begin{array}{l}\text { Centers and group } \\
\text { work }\end{array}$ & Games \\
\hline $\begin{array}{l}\text { Teachers incorporated their } \\
\text { students' } \\
\text { mathematics and sture into their students } \\
\text { classrooms }\end{array}$ & $\begin{array}{l}\text { It takes a } \\
\text { community }\end{array}$ & \\
\end{tabular}




\subsection{The Teachers Used Student-Centered Strategies to Teach Mathematics and Science}

\subsubsection{Discovery learning}

Most teachers used a mix of strategies that enabled students to learn hands-on by working on realworld problems. Discovery learning was Dawn's favorite, as her students worked in groups to create their dream bedroom:

They researched different items on the Internet and then they had to create their own scale drawing. I guess they didn't realize how big stuff was in real life...I want this master bedroom with this master bath, but the room was only so big so maybe we should just do a master bedroom.

This activity was hands on, directly involving the students in different types of measurements, and its outcome was great, as Dawn stated that "after they got through it, I had some really nice designs of room." Similarly, Mitchell's students learned about enzymes:

The students were testing on chicken livers to see enzyme activity; basically, when you take Hydrogen peroxide and the chicken liver, it produces oxygen bubbles. Just the fact that they get to different stations and play around with different things that they would not normally get to play with, interests them alone.

Mary also believed in the significance of engaging her students in discovery learning:

I let them go to the lab and start tinkering with stuff, and then I say, Ok, what did you do? They respond, I don't know, I was just putting stuff together. Then we unpacked that as a class and say, ok when we did this and we didn't follow instructions...this happened. And when this thing happens, it happens because of this, and we call it...then I start working on vocabulary.

Recognizing the benefit of students working hands-on to apply the concepts they learn, Greg stated that this year he engaged his students in labs all the time: "I've done four labs this year; I'm going to do a lab for everything I teach. They love the labs. During a test day, the class feels three hours long. During a lab day, it feels like its thirty minutes long." In such a lab, for example, his students used candy to learn about water molecules:

If I have two gummy bears and one marshmallow, the marshmallow is my oxygen and the gummy bears are my hydrogen. Then they made their water molecule and they had to show me hydrogen bonding. That means someone's marshmallow had to touch someone's gummy bear because hydrogen bonds are oxygen and hydrogen.

In another lab, Alyssa's students learned about the water cycle by placing a bag over a plant to show that plants transpire so that water comes out of leaves: "We used one of these plants, and then they'll see the condensation on the bag. They physically put a bag on top of it and tied it with a rubber band. That way they could actually see the process occurring."

\subsubsection{Centers and group work}

Teachers believed in the power of collaboration between students. Ethan stated: "I am big on collaboration, so I aim to have my students collaborate more." When students collaborate, they rely on each other to arrive at the correct response, as Mitchell reflected:

The fact that their classmates are depending on them holds them accountable. Investing creative energy into something that looks nice helps make it fun, because it is not just know these things and that is it, they actually get have fun with it.

To foster collaboration, Sally and Greg set up their classrooms in centers. At one such center, Sally's students learned about cells: 
At this station we used cell analogies: for example, Officer Jim was our cell membrane, Mr. Sims was our nucleus, batteries were mitochondria. In another center, the students have to use these analogies in a story. It allows everybody something a little different.

In selecting their stations, Greg's students had a variety of choices:

I told them: if you're feeling crafty today, I've got cutting and pasting and working together. If you're feeling artsy, this is the drawing station. If you're feeling creative, join the writing station. If you want to do some hard-core thinking, join this station in which you really have to think. If you need a little more help, come to this station.

While working in groups, Mitchell's students collaborated on macromolecules, and then did a gallery walk: "Each group focused on a particular type of macromolecule and then they walked around and looked at everyone's poster to get the information." Anna engaged her students in social learning: "I like to do pair/group share, I like to have them stand up, speak and share. I like to have a presence so that helps them with their public speaking and things of that nature."

\subsubsection{Games}

To break down the routine and ensure their students had some fun, all the teachers incorporated games into their teaching. Gregg reflected: "If they're laughing, they pay attention, and that helps them stay interested. And if they are interested, I can teach them things." When teaching about ratios, Tammy used a matching game "where they find the person who shares the same ratio that's equivalent," while Courtney's students played a Carousel game: "I have some problems taped up around the room so students have to solve a problem, and the answer to that one will lead them to a problem over there." Although Courtney felt the game was fun, she also felt that "the goal of the activity to get the order right was lost and the kids were like, why can't I just solve it?" To conclude, the teacher reflected on the need to discuss the goal of the game prior to playing it.

Other teachers used manipulatives. Diane's students played cards to learn about positive and negative numbers: "The students dealt the cards out. I would say, what quantity of cards can you get to get zero? I can take and you can take...and we can make a zero out of it?" Moreover, Diane used dice to teach her students about fractions: "I had ten packs of dice with fractions. I would tell them though, if we cannot behave ourselves while we are doing this, I'd take them away and work off the books instead."

Luke's students, on the other hand, enjoyed playing the game "walking through the hood":

Students walk around to different stations. I don't give them a time limit but they have to go to each station and work on problems at their own pace. They walk around and get as much work done with no restrictions. That is what they do in their neighborhood; they walk to play basketball, walk to a friend's house... No restrictions until momma tells you to come home.

Furthermore, Chris, Sally, and Mary's students worked with puzzles. Chris taught his students how to use puzzles in math, while Sally used puzzles to teach about cells in her science class. Similarly, Mary used puzzles to discuss the nature of science:

Every person gets a piece of a puzzle. The piece of puzzle you have is your discovery, but it is not the entire picture. To get the whole picture, you need other people's pieces. When we put all of the pieces together, then we get the whole truth...the whole picture.

Other teachers, like Chris and Courtney, developed review games centered around their students' interests, such as basketball. Chris shared:

I developed a basketball game that I use for review. I have got three basketballs, three garbage cans set up, an A, B and a C and I will post the slide, it has an A B C answer, you work it out and then you shoot. I take tallies when they do it and I make it three points. 
Chris felt that his students "really got into it. I saw some kids trying to do some stuff that they would have never tried. They would have never tried to work on a problem if I had not showed it to them in that way." Similarly, Courtney called her review game trashket ball:

They work in teams, and if their team gets it right, they shoot a piece of paper into the trashcan. They get really excited about it. I will play the music and we have a certain amount of time to answer the question. When the music stops, their time is up, and they hold their whiteboard to show the answer.

Online games were also an important part of the instructional sequence. Cahoots was a favorite for Chris, Greg, Cole, and Tammy. Chris liked Cahoots because "it is a cool online game that holds the kids accountable, because they have to put their names into it. It is almost like taking a quiz." Greg used regular Cahoots "for pre-exit tickets or practice," and blind Cahoots, "where the next question involves information from the previous question. The first question might be "what are macro molecules?" You have to know the answer to this one to get the next one right." Moreover, Adam's students played Math Excel online, Anna used an online game "for science so they are learning while they are playing and they gain points, they really like that," and Dawn used the "Cool math" site to engage her students in logic games, in which her students "have to get things at a certain angle or add really quick."

\subsection{The Teachers Incorporated Students' Culture into their Mathematics and Science Classrooms}

CRT revolves around students' culture. The teachers incorporated students' culture by using students' interests, their community, and by addressing current issues.

\subsubsection{It's all about the students}

To relate to their students, some teachers adopted their students' language. For example, Alyssa and Irene used terminology their students related to. Alyssa's attempt to speak her students' language consist in the use of hashtags: "I talk in their language if that's what they understand. I use vocabulary words that they can understand, and I'll explain words they haven't seen." On the other hand, Irene felt like her language was a barrier in the way she communicated with her students: "The way I speak and the way I act is a barrier. I am not comfortable changing that much, but I find my language is changing a little bit." Anna and Ethan incorporated their students' names in word problems both intentionally: "I try to put names into world problems," (Ethan), or unintentionally: "A student recognized that it was her name, and then other people said, well can you start using my name? And I said, sure" (Anna). On the other hand, Mary used slang in her class:

Even though we are both African American from rough parts of town, our slang is different. For example, back in Baltimore if I say, you are trying to base on me, that means you are being disrespectful...here, the word sounds like basel, which means junkie. My kids will say, Ms. M., did you just call me a basel?

Mary turned this into a teaching moment:

I am like, what are you saying to me because we are not speaking the same language? And they are like, it means this...I take a little break from teaching, I go to the board and I let them be the teacher. This shows I want to understand what you are talking about. Teach me your language, so I know when you are saying things you shouldn't say.

While becoming the experts, Mary's students also learned about the culture within the culture:

Because I am a teacher, you don't get my Baltimore voice. My husband gets my Baltimore voice. They understand that at different times I use different voices. This is called knowing 
where you are and how to respond. And if you don't learn that, you will be crippled later in your life.

Most teachers incorporated their students' interests in the lessons. Andrea and Alyssa appealed to their students' passion for sports. Since Alyssa's students connected best to football, she used "football terminology, as that's what most of my students understand. It also helps that I am big on football." Similarly, Andrea shared:

In math, they like real world applications. You know how in basketball if you step on the line it is out of bounds, but in tennis, it is inbound so that is the difference between less than and equal to. If you remember the analogy, you remember the rule.

Both Mitchell and Adam used their students' interest in dance and music. When teaching about evolution, Mitchell used "The evolution of dance" video, with Will Smith and Jimmy Fallon:

I ask them, did you see the neh neh? No, because these are things from last year, and this video is kind of old. I had some kids who were like, that's how my parents used to dance. We were able to see how dance changed over several generations. Evolution is the same kind of thing.

Adam taught his students about translations, by using the cha-cha-slide:

We talked about translations, which is shifting and moving, and we did the song/dance cha-cha-slide in class. It is all slide, up and down, left to right. The students understand that when you translate it, you stay the same, but you move your position.

On the other hand, Irene connected with her students by educating herself on their music preferences, but at times classroom management issues got in the way:

I am trying to, when they reference music, have you heard that? No, can you write it down for me. I try to...but I feel like so much of my day is spent shutting down off topic conversation, and it is about things like that. This is not something I am doing well with.

Genetics presented itself as a highly interesting topic when discussing evolution. For example, Carmen addressed the topic of skin color:

Genetics is a great place to integrate culture. When I teach evolution, they always make fun of each other for the darker skin; they'll be talking about how black he/she is. I've been teaching them that the darker your skin, the better you've been adapted evolutionary. When I teach Evolution, I can go back in history because some of them want to be called black and some of them want to be called African American.

Greg appealed to his students' interest in the social media:

Kids are raised by the internet, so I incorporate things they are familiar with, like memes. I actually use these in my lesson. I take screen shots of it, so they'll be like, oh, I've seen that before, that was on that website. I am using the internet culture for learning purposes.

Students' interest in the media were also geared towards social justice issues. Sally captured the significance about addressing modern issues related to social injustice beautifully when she said: "When they ask me about stuff that is going on in the world, sometimes we have conversations about it. I get emotional and I don't want them to see that."

Diane's students wanted to discuss the topic of the NFL players kneeling during the national anthem. Asked if they could kneel during the pledge of allegiance, Diane replied:

If you feel the need to take a knee, go for it. But you cannot sit. It is a school policy that you stand. Either stand up and pledge, stand up and do nothing, or take a knee if you want to. I have no problems with that. 
Similarly, Carmen told her students it was ok to sit during the pledge "if you have reasons to back it. However, no talking during it, respect others." Both Chris and Mitchell incorporated social justice issues in their classrooms. While teaching math, Chris brought up Black Lives Matter in word problems:

I had a problem dealing with Black Lives Matter. We talked about numbers, like how many people do I need to have at this rally, how long does it need to take, etc. This is important, I am not only teaching kids how to do math, I am teaching them how to be better people.

Similarly, when teaching environmental science, Mitchell addresses social justice issues: "It is relevant to them, because minorities tend to suffer the most because of environmental issues. I try to frame everything so it's very applicable to their lives."

\subsubsection{It takes a community...}

The communities in which students live are a significant component of their culture. That is why teachers embedded community examples in their science and mathematics lessons. For example, Sally used the church analogy to teach about cells: "I try to make things relatable to them, like our cell analogies. Make it your church, your pastor is your nucleus, right? Ok, where is the cell wall? I don't know if it's necessarily cultural, but it's something they see." Similarly, Ethan engaged students in conversations about how they could improve their community: "I am using their community as a world problem. Either the kind of stores they have in their community, what they want to improve, things like that."

For a more hands-on experience, Anna took her students on nature walks on campus, helping them to "make connections with the types of organisms living within the ecosystem. A student made the connection between the nuclear plant that you see when you are driving over the dames' point with fossil fuel emissions."

Most significantly, students need to be able to relate to successful people. Sally and Carmen introduced their students to African American scientists. Sally stated:

I give them examples of people who look like them. Neil Degrasse Tyson is one of my favorite scientists. Everybody puts up Albert Einstein; he is an old man with white hair. When I use visuals, I try to use people they can relate to, like Neil Degrasse Tyson. I shared a video with him.

Similarly, Carmen stated: "The scientist thing is killing me. I had them write down their favorite scientist. Only one girl wrote down Greg Washington Carver, a black scientist. They don't know others. Albert Einstein is who everyone wrote down...they need to be more aware." Cole also made it his point to introduce new names when talking about oceanography:

The history of Marine Science goes back to the Polynesians going across the Pacific so I try to show it across the entire history of oceanography. Every human culture has been out to sea and has made these advances. I'm looking for more scientists and things I can bring in. Once I get to optics, I know the father of modern optics was a North African.

\section{Discussion}

All teachers used a plethora of student-centered strategies to enhance their students' mathematics and science learning, and they incorporated their students' cultures into their mathematics and science classrooms. These strategies are briefly discussed below in light of the two research questions that guided this study.

\subsection{What Strategies Do Culturally Responsive Teachers Use in Their Mathematics and Science Classroom?}

For the most part, the teachers used strategies that focused on student collaboration. Firstly, some teachers used discovery learning by engaging students in real-life problems. For example, some 
students used chicken livers to test for enzyme activity, others constructed water molecules from candy, while others learned about the water cycle by covering plants with bags to observe condensation. All students were engaged in hands-on activities while conducting a scientific or mathematics investigation. According to Ladson-Billings (2009), culturally responsive teachers apprentice their students in a learning community rather than teach them in unrelated ways. In this way, the students' real-life experiences can become part of the official curriculum.

Secondly, teachers engaged students in collaborative work to increase accountability. The centers allowed for student choice, as they had different levels of complexity, like in Greg's class. Moreover, students engaged in different tasks, from creating things, to writing stories, like in Sally's case. By working together, students taught each other, and they expanded their learning. When students engage in group work, they develop their critical thinking, their social skills, their academic performance, and their cultural sensitivity (Gay, 2000; Kagan, 1994; Powell \& Caseau, 2004).

Thirdly, teachers made learning fun. Some teachers, like Diane and Sally used manipulatives such as cards, dice, or puzzles to make learning more active. Other teachers, like Chris and Courtney, used basketball games to review content, as movement breaks monotony. Chris and Greg's students competed in Cahoots; Adam's students played Math Excell online games. Similarly, Dawn used the "Cool Math" website to engage her students in logic games, and Anna used a science online game in which students would points by playing. Since movement benefits the academic performance of African American students, researchers urged teachers to incorporate music and games into learning (Allen \& Butler, 1996; Gay, 2018).

Researchers (Banks 2011; Gay 2018) cautioned against assuming that all strategies are CRT techniques, as standards for teaching and learning are culturally determined and vary across ethnic groups (Gay, 2000). While some strategies (i.e. cooperative learning strategies) enhance learning in general $(\mathrm{Au}, 2009)$, using these strategies without engaging the students in the construction of knowledge and challenging them to use that knowledge for societal change will not result in equity pedagogy (Banks, 2011). Furthermore, Gay (2018) believed that students need to have choices in the classroom (i.e. which groups they want to work in, what tasks they want to work on, etc.).

\subsection{How Do These Teachers Incorporate their Students' Cultures into Teaching?}

While the teachers in this study used many strategies to motivate their students, they also made sure that these strategies related to students' culture and their interests. Firstly, some teachers eliminated the language barrier, by learning the slang used by their students or by adjusting their language to make themselves understood by their students. Secondly, most teachers used their students' interests to teach specific content. Some used sports to connect with mathematics topics, like Andrea and Alyssa did. Other teachers, like Adam and Mitchell used their students' interests in music and dancing to explain mathematics concepts. Similarly, Carmen used her students' interests in genetics to teach about evolution, when discussing the relation between skin color and environment adaptation.

A few teachers used the media culture to appeal to their students' social culture. Greg, for example, used memes in his science class, to help students connect scientific concepts to everyday life. Chris, Sally, and Diane discussed social justice issues with their students, such as the Black Lives Matter movement, or kneeling for the national anthem. Given the students' interest, teachers extended the latter to talk about the appropriateness of sitting/standing for the Pledge of Allegiance.

Last but not least, some teachers discussed the urgency to use role models their students could relate to (African American scientists and mathematicians, or scientists of African descent), as they found that curriculum continued to exclude marginalized groups (Gay, 2010; Howard, 2010). Ultimately, teachers need to help their students determine the implicit perspectives embedded in curriculum materials and to become more reflective citizens (Banks, 2011), while "teaching explicit 
information about gender contributions, issues, experiences, and achievement effects within ethnic groups." (Gay, 2018, p. 192).

\subsection{On the Way to Becoming Critically Responsive Teachers}

Given the limited data set, it is presumptuous to assume that all the teachers in this study were culturally responsive, or that they were culturally responsive all the time. One teacher interview does not grant a large amount of data, but it grants enough to see instances of CRT taking place. More data need be collected over a period of time to account for intentional CRT. But for this study, the researcher feels comfortable to state that some teachers were making progress towards becoming more culturally responsive. These teachers made attempts to learn about their students' culture and community, and they integrated this knowledge into their curriculum and pedagogy.

Some of the above stories are successful, others are not. One reason for the lack of success of these teachers could be that they did not intentionally used culturally responsive strategies; some stumbled across them and used them spur of the moment, like Anna stated about her using one of her student's names in a word problem. Failure to be more culturally responsive could also be due to a weak classroom management. For example, Irene stated that she spent more time shutting off conversations than focusing on incorporating her students' culture into teaching.

Similarly, Diane used pair work more as classroom management strategy than a culturally structured strategy when her students used the computers, in an attempt to eliminate distractions. In addition, Courtney stated that her Carousel activity was not successful due to poor instructions and expectations for group work. And since classroom management impacts both the classroom and the instruction (Monroe, 2005; Weinstein et al., 2004), a weaker command of classroom management, as in the above cases, lead to unsuccessful classroom activities.

\section{Conclusions and Implications for Future Research}

Teaching and learning are shaped by cultural influences (Ladson-Billings, 2009; Spradlin \& Parsons, 2008). Therefore, teachers need to develop a cultural understanding and minimize any tensions that might arise in their classroom in order to ensure their students are successful at school and at home (Gay, 2018). They can do so by diversifying their techniques and resources (Gay, 2010) and by establishing continuity between the modus operandi of ethnic groups and school cultures in teaching and learning (Spindler, 1987). This implies a mindset in which teachers understand their students' cultures and they use this knowledge to guide curriculum development and use CRT (Banks, 2011; Rychly \& Graves, 2012; Teel \& Obidah, 2008).

Secondly, this mindset starts with the teachers' willingness to learn about their students' culture. But intention without action is not enough (Gay, 2018), so teachers need to educate themselves about their students' cultures and to accompany this knowledge with the skills that help students dismantle the status quo (Banks, 2011; Gay, 2018; Howard, 2010). It may be too early to call the teachers in this study culturally responsive, as CRT is strengthened by time and teaching experience. But what these teachers lacked in experience, they compensated in their willingness to relate to their students. Moreover, all teachers took steps to incorporate students' cultures into the curriculum and pedagogy. This conclusion bears the following implication for research: to gather whether these teachers are indeed culturally responsive, the researcher needs to revisit them in their $2^{\text {nd }}$ and $3^{\text {rd }}$ years of teaching. At this time, the researcher can engage the teachers in conversations about what it means to be a culturally responsive teacher, allowing them to reflect on ways to be intentional about using their students' cultures into their teaching and classroom management strategies.

Finally, given the increased diversity in the student population, CRT should become the reality of today's schools. Gay's (2018) statement bears a sense of urgency: "Finally, students and teachers should become scholars of ethnic and cultural diversity and generate their own curriculum content." (p. 194) Ultimately, teachers, educators, parents, and students, are all responsible to 
create equitable learning environments. All it takes is the willingness to do so, and the action to pursue this desire.

\section{References}

$\mathrm{Au}, \mathrm{K}$. (2009). Isn't culturally responsive instruction just good teaching? Social Education, 73(4), 179-183.

Banks, J. A. (2011). Educating citizens in a multicultural society. New York, NY: Teachers College Press.

Banks, J. A., \& McGee Banks, C. A. (2011). Equity pedagogy and multicultural education. In J. A. Banks (Ed.), Educating Citizens in a Multicultural Society (pp. 78-87). New York, NY: Teachers College Press.

Cavanagh, S. (1997). Content analysis: Concepts, methods and applications. Nurse Researcher, 4(3), 5-16. doi: $10.7748 /$ nr.4.3.5.s2

Crum, M. (2015). Sorry, Ebooks. These 9 studies show why print is better. Huffington Post. Retrieved from http://www.huffingtonpost.com/2015/02/27/print-ebooks-studies_n_6762674.html

Elo, S., \& Kyngäs, H. (2008). The qualitative content analysis process. Journal of Advanced Nursing, 62(1), 107115. doi:10.1111/j.1365-2648.2007.04569.x

Florida Department of Education. n.d. "School District Data". Retrieved from http://www.fldoe.org/schools/k-12-public-schools/school-dis-data.stml

Gay, G. (2002). Culturally responsive teaching: Theory, research, and practice. New York, NY: Teachers College Press.

Gay, G. (2002). Preparing for culturally responsive teaching. Journal of Teacher Education, 53(2), 106-116. doi:10.1177/0022487102053002003

Gay, G. (2010). Culturally responsive teaching: Theory, research, and practice. New York, NY: Teachers College Press.

Gay, G. (2013). Teaching to and through cultural diversity. Curriculum Inquiry, 43(1), 48-70. doi:10.1111/curi.12002

Gay, G. (2018). Culturally responsive teaching. Theory, research, and practice. New York, NY: Teachers College Press.

Giarrizzo, T. (2013). History losing its value: Representation of minorities within high school history. Master's Thesis. St. John Fisher College, Rochester.

Gillies, R. M. (2014). Cooperative learning: Developments in research." International Journal of Educational Psychology, 3(2), 125-140.

Gollnick, D. M., \& Chinn, P. C. (2002). Multicultural education in a pluralistic society. Upper Saddle River, NJ: Merrill Prentice-Hall.

Gullicks, K. A., Pearson, J. C., Child, J. T., \& Schwab, C. R. (2005). Diversity and power in public speaking textbooks. Communication Quarterly, 53(2), 247-258. doi:10.1080/01463370500089870

Howard, T. C. (2010). Why race and culture matter in schools? Closing the gap in America's classrooms. New York, NY: Teachers' College Press.

Kagan, S. (1994). Cooperative learning. San Clemente, CA: Kagan Publishing.

Kroeger, S. D., \& Bauer, A. (2006). Exploring diversity: A video case approach. Upper Saddle River, NJ: Pearson/Merrill Prentice Hall.

Ladson-Billings, G. (2009). The Dreamkeepers: Successful teachers of African American children. San Francisco, CA: Jossey-Bass.

Monroe, C. R. (2005). Why are "bad boys" always black? Causes of disproportionality in school discipline and recommendations for change. Clearing House, 79(1), 45-50. doi:10.3200/tchs.79.1.45-50

Morgan, B. M. (2012). Teaching cooperative learning with children's literature. National Forum of Teacher Education Journal, 22(3), 1-12.

Powell, R. G., \& Caseau, D. (2004). Classroom communication and diversity: Enhancing Instructional practice. Mahwah, NJ: Lawrence Erlbaum Associates. doi:10.4324/9781410610294

Rajgopal, K. (2011). Create success: Unlocking the potential of urban students. Alexandria, VA: Association for Supervision and Curriculum Development.

Raymer, A. (2001). Pedagogy of place facilitation guide: Cultivating and promoting place-based education. Lexington, KY: The Appalachian Rural Education Network and the University of Kentucky Appalachian Center.

Rosenwald, M. S. (2015). Why digital Natives prefer reading in print. Yes, you read that right. The Washington Post. Retrieved from washingtonpost.com/local/why-digital-natives-prefer-reading-in-print-yes-youread-that right/2015/02/22/8596ca86-b871-11e4-9423-f3d0a1ec335c_story.html?utm_term=.ef2194b75fc7. February 2015. 
Rychly, L., \& Graves, E. (2012). Teacher characteristics for culturally responsive pedagogy. Multicultural Perspectives, 14(1), 44-49. doi:10.1080/15210960.2012.646853

Slavin, R. E. (2014). Cooperative learning in elementary schools. International Journal of Primary, Elementary, and Early Years Education, 43(1), 5-14. doi:10.1080/03004279.2015.963370

Sleeter, C. E., \& Grant, C. A. (1991). Race, class, gender, and disability in curriculum textbooks. In M. W. Apple \& L. Christian-Smith (Eds.), The politics of textbooks (pp. 78-110), New York, NY: Routlege.

Spindler, G. D. (1987). Education and cultural process: Anthropological approaches. Waveland, IL: Prospect Heights.

Spindler, G. D., \& Spindler, L A. (1990). The American cultural dialogue and its transmission. London, Falmer Press.

Spradlin, L. K., \& Parsons, R. D. (2008). Diversity matters: Understanding diversity in schools. Belmont, CA: Thomson Wadsworth.

Teel, K. M., \& Obidah, J. E. (2008). Building racial and cultural competence in the classroom. New York, NY: Teachers College Press.

The Center for Technology in Education. n.d. "Characteristics of Urban Education". Retrieved from http://cte.jhu.edu/urbaneducation/ses1_act2_pag1.shtml

Ullucci, K., \& Howard T. (2015). Pathologizing the poor: Implications for preparing teachers to work in highpoverty schools. Urban Education, 50(2), 170-193. doi:10.1177/0042085914543117

US Department of Education. (2016). The state of racial diversity in the education force. Retrieved from www2.ed.gov/rschstat/eval/highered/racial-diversity/state-racial-diversity-workforce.pdf

Vélez-Ibáñez, C. G., \& Greenberg, J. B. (1992). Formation and transformation of funds of knowledge among US-Mexican households. Anthropology \& Education Quarterly, 23(4), 313-335.

Weinstein, C. S., Tomlinson-Clarke, S., \& Curran, M. (2004). Toward a conception of culturally responsive classroom management. Journal of Teacher Education, 55(1), 25-38.

\section{Appendix 1. Teacher Pre and Post Interview}

This interview will last about one hour and I will audiotape the discussion to make sure that it is recorded accurately.

\section{Pedagogy/Classroom Instruction}

1. What teaching strategies do you use to assist students in learning content?

2. How are your learning activities promoting student engagement in mathematics/science?

3. How do you help students make connections with real-life?

4. What are some examples of choices students have in your classroom when it comes to instruction or assessment?

5. How do you assess student learning? Do students have opportunities for self-assessment?

6. How do you integrate students' cultures into your teaching?

\section{Ending the Interview}

Thank you very much for your time and participation in this interview. I would like to remind you that to protect the privacy of this study's participants, all transcripts will be coded with pseudonyms. 